\title{
GOING TO THE DOGS
}

A HISTORY OF GREYHOUND

RACING IN BRITAIN, 1926-2017

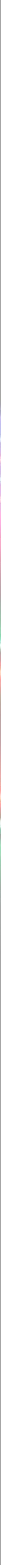




\section{Going to the dogs}

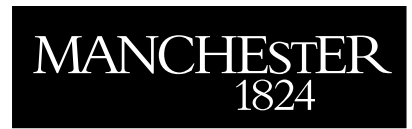

Manchester University Press 
Keith Laybourn - 9781526114525 Downloaded from manchesterhive.com at $04 / 26 / 2023$ 07:49:18AM via free access 


\section{Going to the dogs}

A history of greyhound racing in Britain, 1926-2017

KEITH LAYBOURN

Manchester University Press 
Copyright (C) Keith Laybourn 2019

The right of Keith Laybourn to be identified as the author of this work has been asserted by him in accordance with the Copyright, Designs and Patents Act 1988.

Published by Manchester University Press

Altrincham Street, Manchester M1 7JA

www.manchesteruniversitypress.co.uk

British Library Cataloguing-in-Publication Data

A catalogue record for this book is available from the British Library

ISBN $978 \quad 15261 \quad 14518$ hardback

First published 2019

The publisher has no responsibility for the persistence or accuracy of URLs for any external or third-party internet websites referred to in this book, and does not guarantee that any content on such websites is, or will remain, accurate or appropriate.

Typeset by Out of House Publishing 